\title{
Mortality from benign prostatic hyperplasia: worldwide trends 1950-92
}

\author{
Carlo La Vecchia, Fabio Levi, Franca Lucchini
}

\begin{abstract}
Study objective - To provide a systematic overview of worldwide trends in mortality from benign prostatic hyperplasia (BPH) over the past four decades.

Design - This was a descriptive analysis based on age adjusted mortality rates for BPH between 1950 and 1992 for 41 countries from five continents.

Setting - Official death certifications from the World Health Organization database. Main results - In the 1950 s, the highest age adjusted (on the world standard population) mortality rates for BPH in Europe were in Denmark $(22 \cdot 8 / 100000)$ and Germany (18.1), followed by Scandinavian countries, the UK, and Switzerland. Italy had rates around 10/100 000, and rates were lower in eastern and southern Europe (5-8I 100000 ). Between 1950 and 1990, a fall of over $90 \%$, or even $95 \%$, was observed in most western European countries. Thus, in the early $1980 \mathrm{~s}$, overall mortality from BPH ranged between 0.5 and $1 \cdot 5 / 100000$ in most western European countries. In proportional terms, similar reductions were registered in other developed countries of North America, Asia (that is, Japan or Singapore), and Oceania. $A$ fall in rates was also observed in eastern Europe and in Latin America, particularly from the late 1970s onwards, although these reductions were generally much smaller. Thus, in the early $1990 \mathrm{~s}$, most countries in these areas had BPH rates between 1 and $5 / 100000$. The pattern of trends was, at least qualitatively, similar at younger ages, although most falls were proportionally greater.
\end{abstract}

Conclusions - The most probable interpretation of these trends is that therapeutic improvements - including more widespread and timely surgery, introduction of less invasive techniques, such as transurethral prostatectomy, and possibly the development of medical treatments - have had a favourable and substantial impact on BPH mortality. There are, however, areas of the world, including several countries of western Europe and South America, where rates are still very high.

( $\mathcal{F}$ Epidemiol Community Health 1995;49:379-384)

Falaises 1, CHUV-

Lausanne, Switzerland F Levi

F Lucchini

Correspondence to: Dr F Levi.

Accepted for publication February 1995
Benign prostatic hyperplasia (BPH) is a common condition in elderly men. While it is almost absent below age 45 years, its pathological prevalence is around $30 \%$ at age 50 , and over $50 \%$ above age $70 .{ }^{12}$ The clinical prevalence of symptoms is much lower, however, and has been estimated at around a half to a third of the pathological one. ${ }^{3}$

Certified mortality data on BPH over the past few decades may have been influenced by substantial changes in both the certification and treatment of the disease. Improved diagnosis would, at least in principle, have introduced spurious trends in $\mathrm{BPH}$ rates. Improved treatment - including surgical advancements such as transurethral prostatectomy, with its subsequent developments, and new drug therapies - should, however, have reduced mortality from the disease. ${ }^{4-9}$

There are substantial temporal variations in the adoption of any such procedure in various countries and areas of the world. ${ }^{5710-12}$ To provide a systematic overview of trends in mortality from BPH over the past few decades, we systematically analysed data from 41 countries available through the World Health Organization (WHO) mortality database. This overview has potential therefore to allow priorities to be defined for intervention on a clinical and public health level.

\section{Methods}

Numbers of deaths certified as being caused by BPH between 1950 and 1992 and estimates of the resident population, stratified by sex and five year age group, were derived from copies of the original computer tapes of the WHO mortality database.

\section{COUNTRIES IN THE DATABASE}

Europe

Data were available for the 23 major European countries (United Kingdom was subdivided into England and Wales, Scotland and Northern Ireland), excluding the former Soviet Union, Albania, and a few small countries such as Andorra, Liechtenstein, and Malta.

\section{Americas}

The WHO database contains some data on mortality and population for 49 American countries or territories. All countries with a population of less than 2 million were excluded. Of the 24 countries remaining, only those with age stratified mortality and population figures of sufficient detail were retained: 14 countries were excluded at this stage. The analysis is based on data from Canada, the United States, and the remaining eight Latin American coun- 
tries - Argentina, Chile, Costa Rica, Cuba, Mexico, Puerto Rico, Uruguay, and Venezuela.

Africa

Useful data were available only for Egypt.

Asia

Five countries provided useful data on $\mathrm{BPH}$ mortality over at least part of the calendar period considered: Hong Kong (not an independent country, but a self governing commonwealth), Japan, Singapore, Sri Lanka, and Thailand.

\section{Oceania}

Data were available for Australia and New Zealand.

DATA

Between 1950 and 1992, four different revisions of the International Classification of Dis- eases (ICD) were in operation (from the 6th to the 9 th).${ }^{13-16}$ The ICD codes for BPH under these revisions were, 610 in the 6th and 7 th and 600 in the 8 th and 9 th. No major change was introduced, however, in the coding of deaths from BPH. Certified deaths from $\mathrm{BPH}$ were thus recoded, for all calendar periods and countries considered, according to the 9th revision of the ICD. ${ }^{16}$

Age specific rates for each 5 year age group and calendar period were computed from the matrices of certified deaths and resident populations. In addition to overall age standardised rates, based on the world standard population, ${ }^{17}$ truncated ones at age $45-64$ years were chosen for presentation. The age range 45-64 years was chosen instead of that of 35-64, since there was no information of material relevance to $\mathrm{BPH}$ mortality below age 45 . Truncated rates are of interest for at least two reasons: firstly, they provide specific information on trends in middle age, which have major public health and social relevance, and secondly, death certification in the elderly is generally less re-

Trends in death certification age-standardised (world) rates/100 000 population from benign prostatic hyperplasia in selected countries, 1950-92

\begin{tabular}{|c|c|c|c|c|c|c|c|c|c|c|}
\hline \multirow[t]{3}{*}{ Country } & \multicolumn{5}{|c|}{ Total, all ages } & \multicolumn{5}{|c|}{ Age 45-64y } \\
\hline & \multirow[b]{2}{*}{$1950-54$} & \multirow[b]{2}{*}{$1970-74$} & \multirow[b]{2}{*}{$1985-89$} & \multirow[b]{2}{*}{$1990-92$} & \multirow{2}{*}{$\begin{array}{l}\% \text { of change } \\
1990-92 \\
v 1950-54\end{array}$} & \multirow[b]{2}{*}{$1950-54$} & \multirow[b]{2}{*}{$1970-74$} & \multirow[b]{2}{*}{$1985-89$} & \multirow[b]{2}{*}{$1990-92$} & \multirow{2}{*}{$\begin{array}{l}\text { \% of change } \\
1990-92 \\
\text { v 1950-54 }\end{array}$} \\
\hline & & & & & & & & & & \\
\hline $\begin{array}{l}\text { Europe: } \\
\text { Austria } \\
\text { Belgium } \\
\text { Bulgaria } \\
\text { Czechoslovakia } \\
\text { Denmark } \\
\text { Finland } \\
\text { France } \\
\text { Germany, FRG } \\
\text { (combined since 1990-91) } \\
\text { Greece } \\
\text { Hungary } \\
\text { Iceland } \\
\text { Ireland } \\
\text { Italy } \\
\text { Netherlands } \\
\text { Norway } \\
\text { Poland } \\
\text { Portugal } \\
\text { Romania } \\
\text { Spain } \\
\text { Sweden } \\
\text { Switzerland } \\
\text { UK, England and Wales } \\
\text { UK, Northern Ireland } \\
\text { UK, Scotland } \\
\text { Yugoslavia }\end{array}$ & $\begin{array}{c}12 \cdot 22 * \\
8 \cdot 28^{*} \\
9 \cdot 26+\S \\
8 \cdot 59 \S \\
22 \cdot 85 \S \\
12 \cdot 72 \S \\
5 \cdot 63 \\
18 \cdot 10 \S \\
5 \cdot 74+\S \\
9 \cdot 18^{*} \\
19 \cdot 35 \S \\
11 \cdot 11 \\
10 \cdot 01 \S \\
15 \cdot 26 \\
17 \cdot 56 \S \\
1 \cdot 15^{*} \S \\
5 \cdot 22 * \S \\
9 \cdot 73+\S \\
5 \cdot 10 \$ \\
12 \cdot 35 \S \\
16 \cdot 02 \S \\
16 \cdot 60 \\
17 \cdot 85 \\
15 \cdot 42 \\
5 \cdot 97+\S\end{array}$ & $\begin{array}{r}8 \cdot 53 \\
3 \cdot 67 \\
6 \cdot 20 \\
8 \cdot 01 \\
5 \cdot 31 \\
4 \cdot 86 \\
4 \cdot 56 \\
10 \cdot 41 \\
4 \cdot 30 \\
7 \cdot 74 \\
5 \cdot 89 \\
4 \cdot 92 \\
7 \cdot 19 \\
6 \cdot 32 \\
5 \cdot 02 \\
4 \cdot 20 \\
3 \cdot 22 \\
8 \cdot 76 \\
3 \cdot 77 \\
3 \cdot 91 \\
8 \cdot 06 \\
3 \cdot 65 \\
3 \cdot 79 \\
3 \cdot 18 \\
4 \cdot 69\end{array}$ & $\begin{array}{l}1 \cdot 20 \\
0 \cdot 45 \S \\
1.96 \\
4 \cdot 88 \\
1.49 \\
1 \cdot 25 \\
0 \cdot 88 \\
0 \cdot 90 \\
0 \cdot 59 \\
3 \cdot 23 \\
0 \cdot 87 \S \\
1 \cdot 60 \\
1 \cdot 42 \\
1 \cdot 54 \\
1 \cdot 78 \\
2 \cdot 10 \\
0 \cdot 76 \\
6 \cdot 84 \\
0 \cdot 89 \\
0 \cdot 84 \\
1 \cdot 12 \\
1 \cdot 23 \\
0 \cdot 68 \\
0.79 \\
4 \cdot 08\end{array}$ & 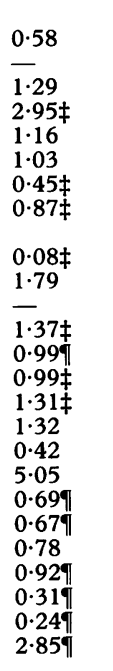 & $\begin{array}{l}-95 \\
-95 \\
-86 \\
-66 \\
-95 \\
-92 \\
-92 \\
-95 \\
-99 \\
-81 \\
-96 \\
-88 \\
-90 \\
-94 \\
-93 \\
+15 \\
-92 \\
-48 \\
-86 \\
-95 \\
-95 \\
-94 \\
-98 \\
-98 \\
-52\end{array}$ & 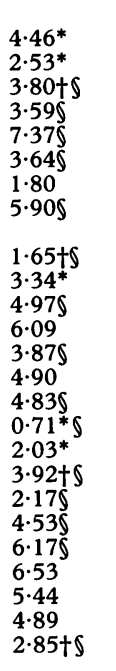 & $\begin{array}{l}1 \cdot 78 \\
1.09 \\
2 \cdot 59 \\
2 \cdot 87 \\
1.08 \\
1 \cdot 12 \\
1 \cdot 17 \\
2 \cdot 22 \\
1.36 \\
2 \cdot 09 \\
2 \cdot 26 \\
1.56 \\
2.02 \\
0.98 \\
0.73 \\
1.53 \\
1.49 \\
3.89 \\
1 \cdot 12 \\
0.77 \\
1.76 \\
0.91 \\
0.73 \\
0.44 \\
2 \cdot 08\end{array}$ & $\begin{array}{l}0 \cdot 23 \\
0 \cdot 09 \S \\
0 \cdot 69 \\
1 \cdot 51 \\
0 \cdot 21 \\
0 \cdot 15 \\
0 \cdot 21 \\
0 \cdot 13 \\
\\
0 \cdot 04 \\
1 \cdot 04 \\
0 \cdot 00 \$ \\
0 \cdot 44 \\
0 \cdot 32 \\
0 \cdot 20 \\
0 \cdot 24 \\
0 \cdot 63 \\
0 \cdot 19 \\
2 \cdot 65 \\
0 \cdot 17 \\
0.08 \\
0 \cdot 13 \\
0 \cdot 38 \oint \\
0.00 \$ \\
0.17 \\
1 \cdot 09\end{array}$ & $\begin{array}{l}0.00 \\
0.38 \\
0.91 \ddagger \\
0 \cdot 12 \\
0 \cdot 24 \\
0 \cdot 09 \ddagger \\
0 \cdot 18 \ddagger \\
0 \cdot 00 \ddagger \\
0 \cdot 49 \\
- \\
0 \cdot 00 \ddagger \\
0 \cdot 339 \\
0 \cdot 03 \ddagger \\
0 \cdot 00 \ddagger \\
0 \cdot 47 \\
0 \cdot 16 \\
2 \cdot 50 \\
0 \cdot 149 \\
0 \cdot 109 \\
0 \cdot 12 \\
0 \cdot 419 \\
0 \cdot 009 \\
0 \cdot 009 \\
0 \cdot 899\end{array}$ & $\begin{array}{l}-100 \\
-96 \\
-90 \\
-75 \\
-98 \\
-93 \\
-95 \\
-97 \\
-100 \\
-85 \\
-100 \\
-100 \\
-91 \\
-99 \\
-100 \\
-34 \\
-92 \\
-36 \\
-94 \\
-98 \\
-98 \\
-94 \\
-100 \\
-100 \\
-69\end{array}$ \\
\hline $\begin{array}{l}\text { America: } \\
\text { Canada } \\
\text { United States } \\
\text { Argentina } \\
\text { Chile } \\
\text { Costa Rica } \\
\text { Cuba } \\
\text { Mexico } \\
\text { Puerto Rico } \\
\text { Uruguay } \\
\text { Venezuela }\end{array}$ & $\begin{array}{l}8 \cdot 42 \\
6 \cdot 95 \\
4 \cdot 27+\dagger ઈ \\
8 \cdot 36^{*} \\
7 \cdot 88+5 \\
5 \cdot 92+\$ \\
2 \cdot 14^{*} \$ \\
2 \cdot 08+5 \\
8 \cdot 62^{*} \\
5 \cdot 16^{*}\end{array}$ & $\begin{array}{l}1 \cdot 74 \\
1 \cdot 28 \\
3 \cdot 429 \\
8 \cdot 53 \\
2 \cdot 34 \\
2 \cdot 85 \\
1 \cdot 54 \\
0 \cdot 77 \\
5 \cdot 01 \\
3 \cdot 32\end{array}$ & $\begin{array}{l}0.38 \\
0.24 \\
0.43 \\
3.35 \\
2 \cdot 78 \\
1.91 \\
2.04 \\
0.20 \\
1 \cdot 19 \\
1 \cdot 75\end{array}$ & $\begin{array}{l}0 \cdot 24 \ddagger \\
0 \cdot 219 \\
0 \cdot 419 \\
- \\
0 \cdot 81 \ddagger \\
2 \cdot 12 \rrbracket \\
1 \cdot 62 \ddagger \\
0 \cdot 29 \ddagger \\
1 \cdot 759 \\
-\end{array}$ & $\begin{array}{l}-97 \\
-97 \\
-90 \\
-60 \\
-90 \\
-64 \\
-24 \\
-86 \\
-80 \\
-66\end{array}$ & $\begin{array}{l}3 \cdot 53 \\
4 \cdot 21 \\
2 \cdot 65+t \S \\
6 \cdot 35^{*} \\
3 \cdot 49+5 \\
2 \cdot 15+5 \\
1 \cdot 62^{*} \$ \\
1 \cdot 21+\$ \\
6 \cdot 50^{*} \\
4 \cdot 26^{*}\end{array}$ & $\begin{array}{l}0 \cdot 49 \\
0 \cdot 46 \\
1.93 \S \\
5 \cdot 01 \\
2 \cdot 03 \\
1.42 \\
0.97 \\
0 \cdot 30 \\
3 \cdot 13 \\
3 \cdot 54\end{array}$ & $\begin{array}{l}0.08 \\
0.08 \\
0.26 \\
1.26 \\
1.02 \\
1 \cdot 16 \\
0.83 \\
0.08 \\
0.42 \\
1.01\end{array}$ & $\begin{array}{l}0.04 \ddagger \\
0.079 \\
0 \cdot 239 \\
- \\
0.00 \ddagger \\
0 \cdot 839 \\
0.49 \ddagger \\
0.39 \ddagger \\
0.359 \\
-\end{array}$ & $\begin{array}{l}-99 \\
-98 \\
-91 \\
-80 \\
-100 \\
-61 \\
-70 \\
-68 \\
-95 \\
-76\end{array}$ \\
\hline $\begin{array}{l}\text { Africa: } \\
\text { Egypt }\end{array}$ & $7 \cdot 47^{*}$ & $3 \cdot 08$ & $1 \cdot 11^{* *}$ & - & -85 & $8 \cdot 11^{*}$ & $3 \cdot 85$ & $0.99 * *$ & - & -88 \\
\hline $\begin{array}{l}\text { Asia: } \\
\text { Hong Kong } \\
\text { Japan } \\
\text { Singapore } \\
\text { Sri Lanka } \\
\text { Thailand }\end{array}$ & $\begin{array}{l}3 \cdot 59 \dagger \\
1.16 \\
1.68+\varsigma \\
1.67 \\
0.12 * \$\end{array}$ & $\begin{array}{l}1 \cdot 83 \\
1 \cdot 78 \\
2 \cdot 89 \\
0 \cdot 71++5 \\
0 \cdot 06\end{array}$ & $\begin{array}{l}0.33 \S \\
0.35 \\
0.23 \S \\
0.04 \S \\
0.02 \S\end{array}$ & $\begin{array}{l}\overline{0 \cdot 21} \\
- \\
-\end{array}$ & $\begin{array}{l}-91 \\
-82 \\
-86 \\
-98 \\
-83\end{array}$ & $\begin{array}{l}0 \cdot 87 \dagger \\
0.50 \\
0.54+\varsigma \\
2 \cdot 64 \\
0.09 * \delta\end{array}$ & $\begin{array}{l}0.43 \\
0.32 \\
1.04 \\
0.84++5 \\
0.01\end{array}$ & $\begin{array}{l}0.08 \$ \\
0.02 \\
0.00 \$ \\
0.09 \$ \\
0.03 \$\end{array}$ & $\begin{array}{l}- \\
0.01 \\
- \\
-\end{array}$ & $\begin{array}{l}-91 \\
-98 \\
-100 \\
-97 \\
-67\end{array}$ \\
\hline $\begin{array}{l}\text { Oceania: } \\
\text { Australia } \\
\text { New Zealand }\end{array}$ & $\begin{array}{l}15 \cdot 17 \\
12 \cdot 64\end{array}$ & $\begin{array}{l}3.54 \\
3.97\end{array}$ & $\begin{array}{l}0.79 \\
1 \cdot 17\end{array}$ & $\begin{array}{l}0.54 \\
0.68 \ddagger\end{array}$ & $\begin{array}{l}-96 \\
-95\end{array}$ & $\begin{array}{l}5 \cdot 97 \\
4 \cdot 84\end{array}$ & $\begin{array}{l}0.90 \\
1.23\end{array}$ & $\begin{array}{l}0 \cdot 19 \\
0.12\end{array}$ & $\begin{array}{l}0 \cdot 10 \\
0 \cdot 30 \ddagger\end{array}$ & $\begin{array}{l}-98 \\
-94 \\
\end{array}$ \\
\hline
\end{tabular}

* 1955-59 only available; $+1960-64$ only available; $¥ 1990-91$ only available; $\lceil$ one or more years were missing; | 1990 only available; ** $1980-84$ only available; $+\uparrow 1965-69$ only available. 
liable, and may, therefore, introduce spurious trends in rates.

Data were missing for part of one or more calendar periods in a few countries. When a single year was missing within a quinquennium, numerators and denominators were interpolated linearly from the previous and subsequent calendar year. No extrapolation was made for missing data at the beginning or the end of the calendar period considered, or when data on one or more quinquennia were not available.

\section{Results}

Table 1 gives the age standardised death certification rates from $\mathrm{BPH}$ at all ages and trun-
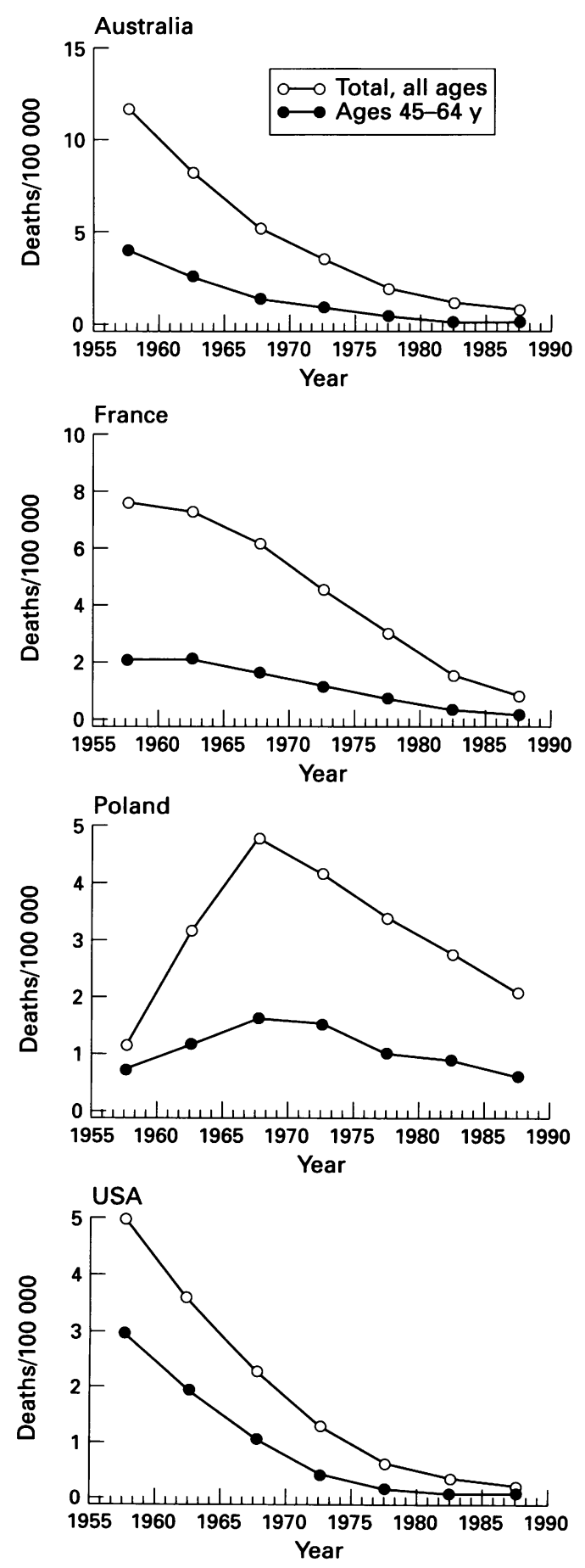

cated rates from 45 to 64 years in the 41 countries considered, together with the percentage changes in mortality from 1950-54 to 1990-92 (or the last calendar period available). To provide more comprehensive information on a few specific patterns of trends, Figure 1 gives trends in BPH rates for eight selected countries. Further, to offer a summary picture of the range of variations in BPH mortality over the last few years, age standardised rates for the period 1990-92 for various countries are given in histogram form in Figure 2.

EUROPE

In the 1950 s, the highest age standardised mor-
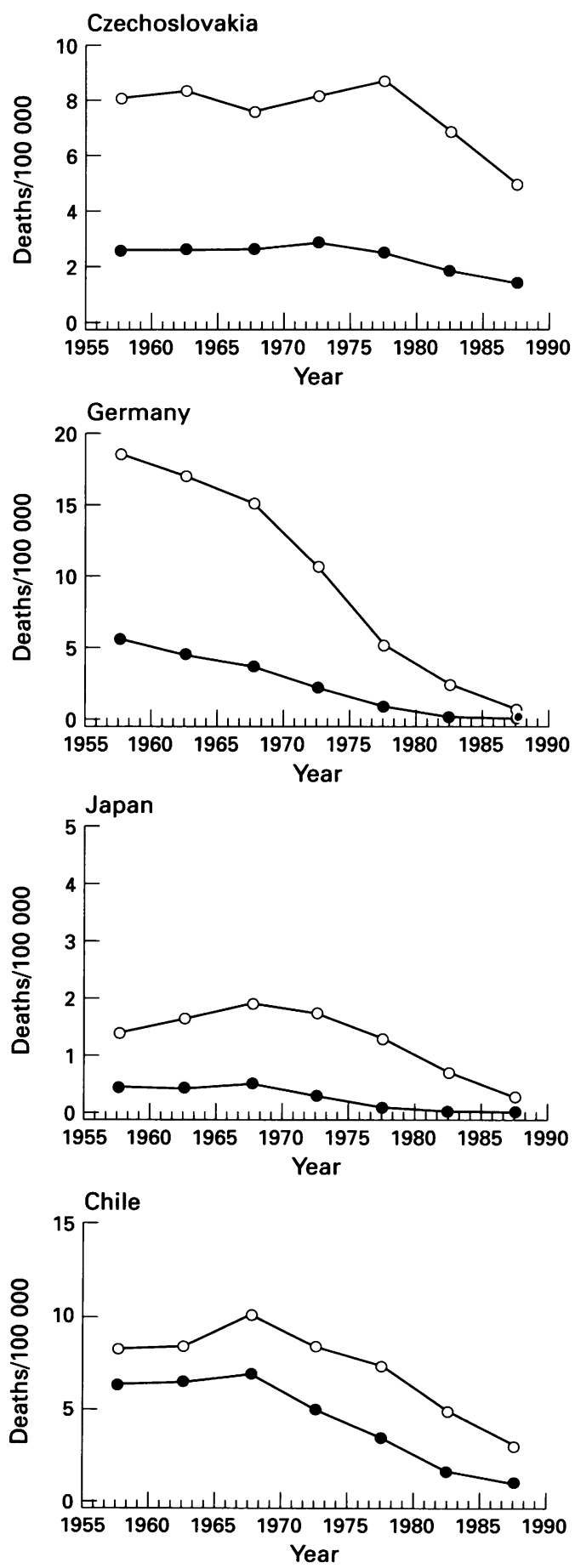

Figure 1 Trends in overall mortality and 45-64 years age standardised (world) mortality from benign prostatic hyperplasia in selected countries, 1955-89. 

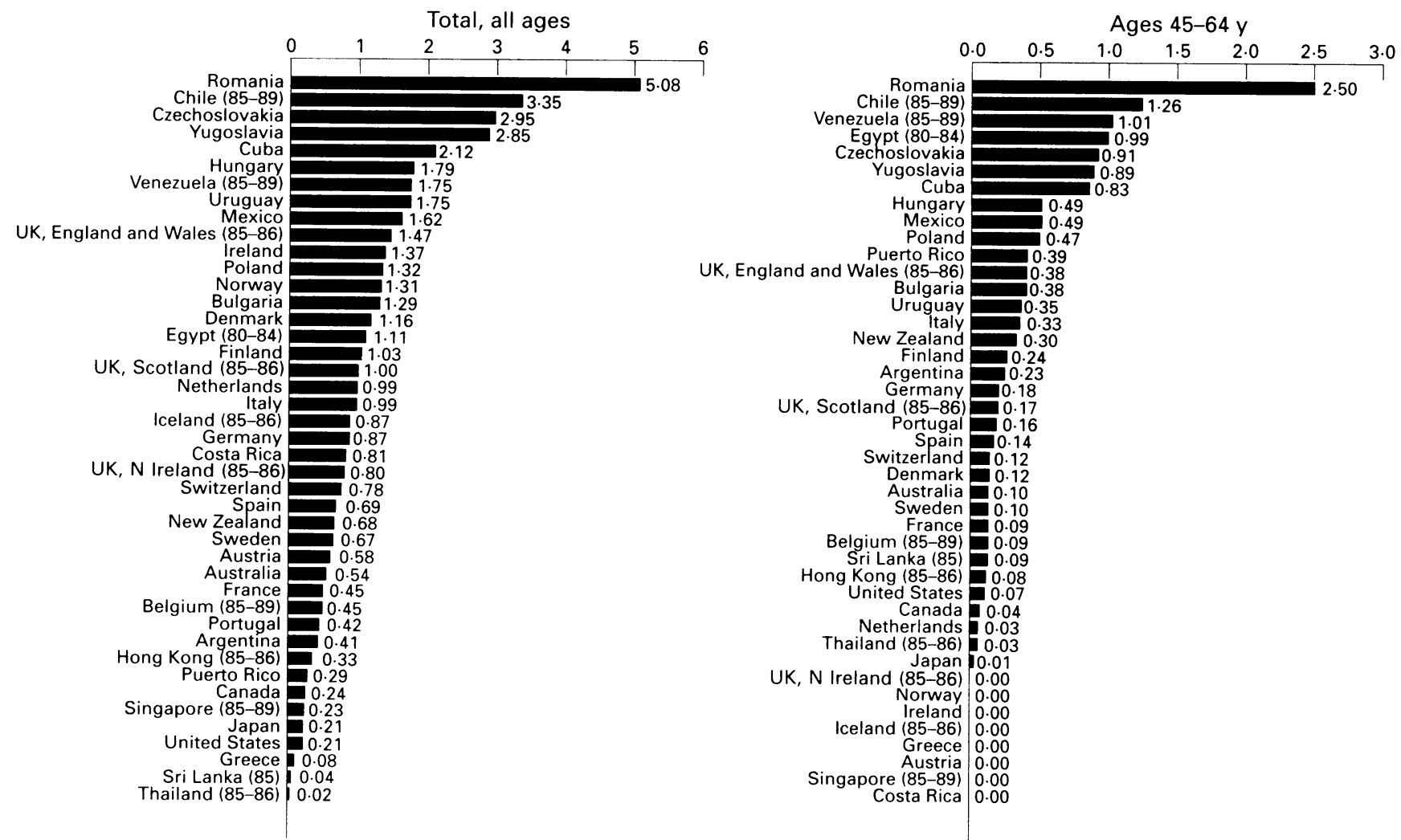

Figure 2 Overall and truncated age standardised (world) mortality from benign prostatic hyperplasia $1990-92$ (unless mentioned in parentheses).

tality rates from $\mathrm{BPH}$ were in Denmark (22.9/ $100000)$ and Germany (18.1), followed by Norway $(17 \cdot 6)$, the UK (15 to 18$)$, Switzerland $(16 \cdot 0)$, The Netherlands $(15 \cdot 3)$, other Scandinavian countries (12-13), and Austria (12·2). Italy had rates around 10/100 000, while those in eastern Europe, Belgium, France, Spain, Portugal and Greece were lower (between 5 and $9 / 100000$ ). Inspection of the age specific rates indicates that there were substantial differences between various countries across subsequent age groups, although these were often and apparently larger at elderly ages. Still, a noticeable heterogeneity of $\mathrm{BPH}$ rates was evident even at younger ages. For instance, $\mathrm{BPH}$ mortality rates in $1950-54$ for the age group 45 to 64 years were $7 \cdot 4$ in Denmark and 5.9 in Germany, but only $1.8 / 100000$ in France.

Over the four decades considered, there were steady and substantial downward trends in $\mathrm{BPH}$ mortality in all western European countries. In the late 1980 s or early 1990 s, overall mortality ranged between 0.5 and $0.9 / 100000$ in France, Belgium, Germany, Greece or Portugal, and 1.2 and 1.5 in Denmark, Italy, and Ireland. The downward trends were observed consistently across various age groups, but tended to be greater at younger ages.

Some decline in rates was also observed in eastern European countries, particularly from the late 1970 s onwards. However, the reduction was much smaller than in western countries. Thus, BPH mortality fell from $8 \cdot 6 / 100000$ in $1953-54$ to 3.0 in 1990 in Czechoslovakia, from 12.9 to 4.3 in the former German Democratic Republic, from 9.2 to 2.0 in Hungary, from $9 \cdot 7$ to $5 \cdot 1$ in Romania, and from $6 \cdot 0$ to
2.9 in the former Yugoslavia. Only in Bulgaria was the fall appreciable (from 9.3 to 1.3 ), and in Poland mortality declined from 4.8 in $1965-69$ to $1 \cdot 3 / 100000$ in 1990 . Consequently, Romania, former Yugoslavia, Czechoslovakia, and Hungary had some of the highest BPH mortality rates in the world (fig 2 ). In addition, the decline in Eastern Europe was somewhat larger at a younger age.

\section{AMERICAS}

Mortality from BPH in the early 1950s in Canada and the United States was relatively low (7-8.4/100 000). Moreover, in both countries a substantial and steady decline was observed over the past few decades. Thus, in 1985-89, the age standardised mortality rates were $0 \cdot 38 / 100000$ males in Canada, and $0 \cdot 24$ in the USA - two of the lowest rates in the world. In both countries, the fall in rates was substantial in all subsequent age groups, including the elderly one. The decline was appreciable also in Puerto Rico and Argentina, whose rates were $0 \cdot 2$ and $0 \cdot 4 / 100000$ in the late 1980 s.

$\mathrm{BPH}$ death rates in the 1950 s were also comparatively low in most other American countries that provided data for the WHO dataset, but the falls in rates were appreciably smaller. The declines in the overall age standardised rates were from 8.4 to 3.4 in Chile, 7.9 to $2 \cdot 8$ in Costa Rica, $2 \cdot 1$ to 1.9 in Mexico, $8 \cdot 6$ to 1.2 in Uruguay, and 5.2 to 1.8 in Venezuela. Chile, Cuba, and a few other Latin American countries therefore had some of the highest death rates from $\mathrm{BPH}$. 
AFRICA

Useful data on BPH mortality were available only from Egypt. These showed a substantial decline (from $7 \cdot 5$ to $1 \cdot 1 / 100000$ males, all ages), which was also reproduced in age specific rates for various age groups.

\section{ASIA}

In the 1950 s, death rates from BPH in the few Asian countries that provided data were low on a worldwide scale $(3 \cdot 6 / 100000$ in Hong Kong, 1.2 in Japan, and 1.7 in Singapore). Substantial reductions were observed nonetheless over the last few decades, and rates in the late 1980 s or early 1990 s were around $0 \cdot 2$ / 100000 in these countries (three of the lowest rates in the world). The reductions were observed in various age groups, but were larger at younger ages.

\section{OCEANIA}

In the early $1950 \mathrm{~s}$, the overall age adjusted $\mathrm{BPH}$ rates were $15 \cdot 2 / 100000$ in Australia and 12.6 in New Zealand. These fell in the late 1980 s to 0.8 and 1.2 respectively. In New Zealand, but less clearly in Australia, the fall in rates was smaller in the elderly, that is, those above the age of 75 .

\section{Discussion}

This overview of trends in mortality from BPH in various areas of the world shows a fall of over $90 \%$ - and often over $95 \%$ - in death rates in developed countries. In recent years, therefore, death from $\mathrm{BPH}$ has become a rare event, particularly in countries like Canada, the United States, or Japan. In contrast, however, and despite some reduction in rates, mortality from BPH was persistently and substantially higher in several countries of eastern Europe and South America.

BPH is practically absent below age 40 , but has a prevalence in pathology series of over $50 \%$ above age 70 years. ${ }^{218}$ Besides a major role of age and of normal testicular function, since the disease does not develop in men castrated before puberty, ${ }^{19}$ there is no other defined and strong risk factor for the disease. Associations have been reported with liver cirrhosis, hypertension, vasectomy, indicators of sexual activity, race, and religious group, ${ }^{12021}$ but none can be clearly and consistently related to changes and trends in death rates observed in various countries over the past four decades.

Part of the observed variation is attributable to the variable degree of accuracy of certification in various countries and areas of the world. Thus, several countries of southern and eastern Europe, Latin America, and Asia probably have a lower quality of death certification data than countries of northern Europe, America, and Japan. This can hardly explain the consistent pattern registered over time, however, or the observation of similar trends in middle age men, in whom death certification is more reliable. ${ }^{2223}$ There are limited data on the incidence or pathological prevalence of
BPH. Necropsy studies on $\mathrm{BPH}$ in various areas of the world have not found major differences in age specific prevalences, ${ }^{2425}$ and in studies from North America and Europe no substantial patterns in incidence have been observed. ${ }^{1}$

Changed diagnostic approaches and increased attention to prostate disease should, it anything, have increased the diagnosis and certification of BPH. Mortality from BPH may be due to renal failure, urological infections that cause pyelonephritis and sepsis, acute urinary retention, but is essentially a result of complications of therapy. ${ }^{12627}$ Thus, the most likely interpretation of the favourable trends observed is that therapeutic improvements have had a favourable and substantial impact on death rates from the disease. In most North American and northern European countries and in Oceania, these therapeutic improvements (and the subsequent falls in rates) have been observed since the $1950 \mathrm{~s}$, whereas in southern Europe or Japan they have started in the late 1960 s or early 1970 s. The therapeutic advancements include more widespread and timely application of surgery, the introduction of less invasive techniques, such as transurethral prostatectomy, and its subsequent developments (with laser or microwave technology), and possibly the development of more effective medical treatments. ${ }^{3-5}$ Thus, in the United States, the age adjusted rate of radical prostatectomy in 1990 was over fivefold that of $1984 .^{7}$

Although more widespread and timely surgery seems to have had a major impact on $\mathrm{BPH}$ rates worldwide, whether the persisting wide variation in prostatectomy rates in various developed countries has had any substantial impact on BPH mortality is still debatable. ${ }^{10}$

These uncertainties and any other limitation of the data notwithstanding, the results of this study clearly indicate that there are areas of the world - including several countries of eastern Europe and South America - where the management of BPH is far from optimal, and where death rates from such an avoidable disease are still high. In these areas, the introduction of modern management techniques would be important on a public health scale.

1 Guess HA. Benign prostatic hyperplasia: antecedents and natural history. Epidemiol Rev 1992;14:131-53.

2 Boyle P, McGinn R, Maisonneuve P, La Vecchia C. Epidemiology of benign prostatic hyperplasia: present knowledge and studies needed. Epidemiol Urol 1991;20(suppl 2): 3-10.

3 Garraway WM, Collins GN, Lee RJ. High prevalence of benign prostatic hypertrophy in the community. Lance 1991;338:469-71.

4 Fernandez E, Porta M, Alonso J, Antò JM. Epidemiology of prostatic disorders in the city of Barcelona. Int $\mathcal{f}$ Epidemio 1992;21:959-65.

5 Kirk D. How should new treatments for benign prostatic hyperplasia be assessed? $B M \mathcal{F}$ 1993;306:1283-4.

6 Bdesha AS, Bunce CJ, Kelleher JP, Snell ME, Vukusic J Witherow RO'N. Transurethral microwave treatment fo benign prostatic hypertrophy: a randomised controlled clinical trial. BMF 1993;306:1293-6.

7 Lu-Yao GL, McLerran D, Wasson J, Wennberg JE. An assessment of radical prostatectomy. Time trends, graphic variation, and outcomes. $f A M A$ 1993;269:2633 36.

8 Hunter DJW, McKee CM, Sanderson CFB, Black NA. Appropriate indications for prostatectomy in the UK 1994;48:58-64.

9 Gormley GJ, Stoner E, Bruskewitz RC, et al. The effect of 
finasteride in men with benign prostatic hyperplasia. $N$ Engl f Med 1992;327:1185-91.

10 McPherson $K$, Wennberg JE Hovind OB, Clifford P. Small area variations in the use of common surgical procedures: an international comparison of New England, England, and Norway. $N$ Engl $f$ Med 1982;397:1310-14.

11 Anonymous. Radical prostatectomies - Wisconsin, 1982 1992. MMWR 1993;42:620-7.

12 Stephenson WP, Chute CG, Guess HA, et al. Incidence and outcome of surgery for benign prostatic hyperplasia among residents of Rochester, Minnesota: 1980-87. A population-based study. Urology 1991;38(suppl 1):32-42.

13 World Health Organization. International classification of diseases. 6th Rev. Geneva: World Health Organization, 1950.

14 World Health Organization. International classification of diseases. 7th Rev. Geneva: World Health Organization, 1957.

15 World Health Organization. International classification of diseases. 8th Rev. Geneva: World Health Organization, 1967.

16 World Health Organization. International classification of diseases. 9th Rev. Geneva: World Health Organization, 1977.

17 Doll R, Smith PG. Comparison between registries: agestandardized rates. In: Waterhouse JAH, Muir C, Shanmugaratnam K et al. eds. Cancer incidence in five Shanmugaratnam $\mathrm{K}$ et al. eds. Cancer incidence in five
continents. Vol 4. IARC Scientific Publication no 42. Lyons: International Agency for Research on Cancer, 1982; 671-5.

18 Sidney S, Quesenberry CP Jr, Sadler MC, Guess HA Lydick EG, Cattolica EV. Incidence of surgically treated benign prostatic hypertrophy and of prostate cancer among black and whites in a prepaid health care plan. $A m \mathcal{F}$ Epidemiol 1991;134:825-9.

19 Wilson JD. The pathogenesis of benign prostatic hyperplasia. Am ₹ Med 1980;68:745-56.

20 Glynn RJ, Campion EW, Bouchard GR, Silbert JE. The development of benign prostatic hyperplasia among volunteers in the normative aging study. Am $\mathcal{f}$ Epidemiol $1985 ; 121: 78-90$.

21 Morrison A. Risk factors for surgery for prostatic hypertrophy. Am f Epidemiol 1992;135:974-80.

22 Doll R, Peto R. The causes of cancer: quantitative estimates of avoidable risks of cancer in the United States today. $\mathcal{F}$ Natl Cancer Inst 1981;66:1191-308.

23 Boyle P. Relative value of incidence and mortality data in cancer research. Recent Results Cancer Res 1989;114: 41-63.

24 Isaacs JT, Coffey DS. Etiology of disease process of benig prostatic hyperplasia. Prostate 1989;2(suppl):33-50.

25 Bostwick DG, Sole Balcells F, Cooner WH, et al. Benign prostatic hyperplasia (BPH) and cancer of the prostate. In: Cockett ATK AsO Y Chatain $\mathrm{C}$, al, eds. Prostace. f a consultation on benign prostatic hyperplasia (BPH). Geneva,

26 Barry MJ. Epidemiology and natural history of benign prostatic hyperplasia. Urol Clin North Am 1990;17:495-507. 27 Birkhoff JD. Natural history of benign prostatic hypertrophy. In: Hinman F Jr, ed. Benign prostatic hypertrophy. New York: Springer-Verlag, 1986:10-21. 